\title{
KOUŘENÍ U SENIORŮ
}

Smoking in seniors

\section{Kvetoslava Kotrbová1,2, František Kotrba ${ }^{2,3}$, Vladimír Vurm ${ }^{1}$}

1Jihočeská univerzita v Českých Budějovicích, Zdravotně sociální fakulta, katedra veřejného a sociálního zdravotnictví

2Krajská hygienická stanice Jihočeského kraje se sídlem v Českých Budějovicích

3Jihočeská univerzita v Českých Budějovicích, Zdravotně sociální fakulta, katedra veřejného a sociálního zdravotnictví, student doktorského studia

\section{Summary}

The prevalence of smoking as a topical health problem in most countries exerts a moderate decrease in the tobacco consumption over the last years, particularly among men and older age groups, but an increasing trend among women and particularly younger age groups and children, which are also primarily targets not only of the marketing attempts of tobacco companies but also of most contemporary research programmes. Thus, the authors aimed their work, in association with holding the conference Problems of Generation 50 plus, which is regularly co-organized by the Faculty of Health and Social Studies of the University of South Bohemia, at following the population on the opposite group compared to most studies: a group of seniors - students of the University of Third Age of the Faculty of Health and Social Studies of the University of South Bohemia in České Budějovice and former students, members of the Club of the University of the Third Age.

The sample group consisted of people having active approach to their lives, who are interested in acquiring new information even at their advanced age. The authors examined their standpoints and habits in the field of the consumption of tobacco, effects of advertisements, health education, economical problems and health condition.

The principal result is the fact that most smokers considered were able to stop smoking. The authors worked with a sample of 97 subjects aged 50 to 85 years; the average age was of 64.5 years. Forty-three respondents of the total number of 97 stated that they were smoking sometimes in the past. Today, only 6 persons are smoking; 37 smokers stopped smoking, i.e. $86 \%$ of the subjects, who were regularly smoking for a period longer than one year sometimes in the past. A further interesting finding is the opinion of subjects that neither the prevention nor the advertisements of tobacco products played any role in forming their standpoints and opinions as usually considered. The most important factor why they started smoking was supporting their status in an informal group - crowd; the most frequent reason for which they stopped smoking were fears of health consequences of smoking.

Key words: smoking - nicotine - seniors - dependence

\section{Souhrn}

Prevalence kouření jako aktuálního zdravotního problému drtivé většiny zemí vykazuje v posledních letech mírný pokles spotřeby tabáku především mezi muži a staršími věkovými skupinami, avšak stoupající trend mezi ženami a především mladšími věkovými skupinami a dětmi, kam je také primárně cílen nejen marketing tabákových firem, ale i většina současných výzkumů. Tuto práci proto autoři zaměřili v souvislosti s konáním konference Problematika Generace 50 plus, jíž je Zdravotně sociální fakulta Jihočeské univerzity pravidelným spolupořadatelem, na sledování věkově opačného pólu, než jaký je cílem většiny studií, na skupinu seniorů - současných studentů Univerzity třetího věku Zdravotně sociální fakulty Jihočeské univerzity v Č. Budějovicích a jejích studentů bývalých, členů Klubu Univerzity třetího věku. 
Sledovanou skupinu tvořili lidé, kteří přistupují aktivně ke svému životu a i ve zralém věku jsou aktivní v získávání nových informací. Autoři zkoumali, jaké měli a mají postoje a návyky v oblasti konzumace tabáku, jak je ovlivňovala reklama, zdravotnická osvěta, ekonomické otázky a zdravotní stav.

Základním zjištěním je fakt, že s kouřením dokázala skončit velká většina sledovaných kuřáků. Autoři pracovali se vzorkem 97 respondentů ve věku mezi padesáti až pětaosmdesáti roky, průměrný věk byl 64,5 roku. Čtyřicet tři respondenti z celkového počtu 97 uvedli, že někdy v minulosti kouřili. Dnes kouří pouze 6 osob, kouřit přestalo 37 kuřáků, tedy plných $86 \%$ z těch respondentů, jež někdy v minulosti pravidelně déle než rok kouřili. Dalším zajímavým zjištěním je názor respondentů, že ani prevence, ani reklama na tabákové výrobky nehrály při utváření jejich postojů a názorů roli, jež se jí obecně přisuzuje. Nejdůležitějším faktorem, proč začínali kouřit, bylo potvrzení jejich statutu v neformální skupině - partě, nejčastějším důvodem, proč přestali, byly obavy ze zdravotních následků kouření.

Klíčová slova: kouření - nikotin - senioři - závislost

\section{CÍLE VÝZKUMU}

V kontextu problematiky Generace 50 plus autory zajímal vztah seniorů ke kouření jako problému naučeného chování, které si kuřák fixuje radu let. Cílem výzkumu bylo zjistit prevalenci kouření tabáku ve sledované skupině seniorů v minulosti a v současnosti, důvody, proč s kouřením před lety začínali, jaký vývoj měla jejich kuřácká kariéra a jaké aspekty zdravotní, sociální a jiné ji ovlivňovaly. Zjišt'ovali jsme též postoje seniorů $\mathrm{k}$ problematice zdravého životního stylu.

\section{CHARAKTERISTIKA SOUBORU}

Autoři rozdali s krátkým seznamovacím komentářem dotazník 98 studentům Univerzity třetího věku ZSF JU v Českých Budějovicích a jejím absolventům, členům Klubu Univerzity třetího věku. Respondenty tedy byli vesměs lidé, kteři prristupují aktivně ke svému životu v oblasti vzdělání a psychického rozvoje, tudíž lze předpokládat i aktivní a informovaný přístup ke svému zdraví fyzickému. Předesíláme, že některé závěry mohou být kvalitou zkoumané skupiny a jejím složením, kde drtivě převažovaly ženy, ovlivněny. Předpokládejme proto, že skutečný stav zbytku populace bude odlišný co do informovanosti respondentů a jejich aktivního př́stupu mj. k vlastnímu zdraví, tudíž i co do kvality jejich názorů, postojů a chování v této problematice.

Jeden z 98 dotazníků jsme vyřadili pro jeho neúplnost (response rate 98,98\%), pracovali jsem tedy se skupinou 97 respondentů, kterou tvořilo 81 žen a 16 mužů. Průměrný věk respon- dentů byl 64,5 roku. Odpovídaly osoby ve věkovém rozpětí mezi padesáti až osmdesáti pěti roky věku.

\section{POUŽITÁ VÝZKUMNÁ METODA}

Jako základní metodu výzkumu jsme použili dotazník, který vyplňovali respondenti sami a anonymně. Dotazník obsahoval čtrnáct otázek, sedm z nich charakterizovalo respondenty a jejich návyky, sedm pak zjišt'ovalo jejich názory a postoje $\mathrm{k}$ problematice kouření a zdravého životního stylu, většina otázek obsahovala podotázky.

\section{VÝSLEDKY VÝZKUMU}

\section{Kouří pouze šest procent seniorů}

V současné době kouří $6 \mathrm{z}$ celkového počtu 97 respondentů, tedy šest procent ze sledované skupiny. Někdy v minulosti kourrilo pravidelně $43(44 \%)$ respondentů, nikdy pravidelně nekouřilo $54(56 \%)$ respondentů. Z celkového počtu 43 pravidelných kuřáků přestalo z nějakých důvodů v minulosti kouřit 37 kuřáků, což je $86 \%$ ze všech sledovaných kuřáků! Průměrný věk první vykouřené cigarety byl ve skupině 43 sledovaných kuřáků 17,5 roku. Modus, tedy nejčastěji udávaný věk první cigarety, byl 18 let. Rozpětí prvních experimentů s konzumací tabáku se pohybovalo mezi dvanáctým až pětatřicátým rokem života respondentůkuráků.

Interval mezi prvními experimenty s kouřením a začátkem pravidelného kouření trval průměrně 4 roky, nejčastěji udávaným intervalem byly dva roky. 
Zajímavým údajem je, že zhruba v deseti procentech případů nastala u sledovaných kuřáků závislost na tabáku okamžitě!

$\mathrm{V}$ průměru začali kuřáci ze sledované skupiny kouřit ve 20 letech a třech měsících svého věku, modus byl 20 let a věkové rozpětí začátku pravidelného kuráctví se pohybovalo mezi 12.35 rokem kourících respondentů.

$\mathrm{V}$ průměru pravidelně kourili sledovaní kuřáci dvacet let, sedm měsíců a deset dnů svého dosavadního života. Nejčastěji uváděli délku kouření 10 let, rozpětí délky kouření bylo 1 rok až 57 let pravidelného kouření. V této souvislosti jednu poznámku: Rozdíly v úmrtnosti kuráků a nekuřáků se epidemiologicky projevují po dvaceti letech kuřáctví.

\section{Každý druhý kuřák se pokoušel přestat}

Průměrně vykouřili sledovaní kuřáci 12 cigaret denně, rozpětí se pohybovalo od symbolické jedné cigarety denně po čtyřicet vykouřených cigaret denně. Zhruba každý druhý z kourrících, přesněji $22(51 \%)$ z kuřákủ ze skupiny, se někdy $\mathrm{v}$ minulosti pokoušel opakovaně přestat kourit. Nejvýznamnějším motivačním faktorem pro skoncování s kouřením byly všeobecně faktory zdravotní. Respondenti měli možnost uvést i více odpovědí. Osmnáct ze 43 respondentů kuřáků, tedy 42 procent, jako hlavní důvod uvedlo strach z možných zdravotních následků (graf č. 1). Pro necelou třetinu ze skupiny kuřáků - celkem 13 respondentů (30 \%) - byly hlavním důvodem vlastní zdravotní problémy či prríčiny - těhotenství, onemocnění dýchacího ústrojí či srdce.

Graf č. 1 - Kvưli čemu dokázali přestat

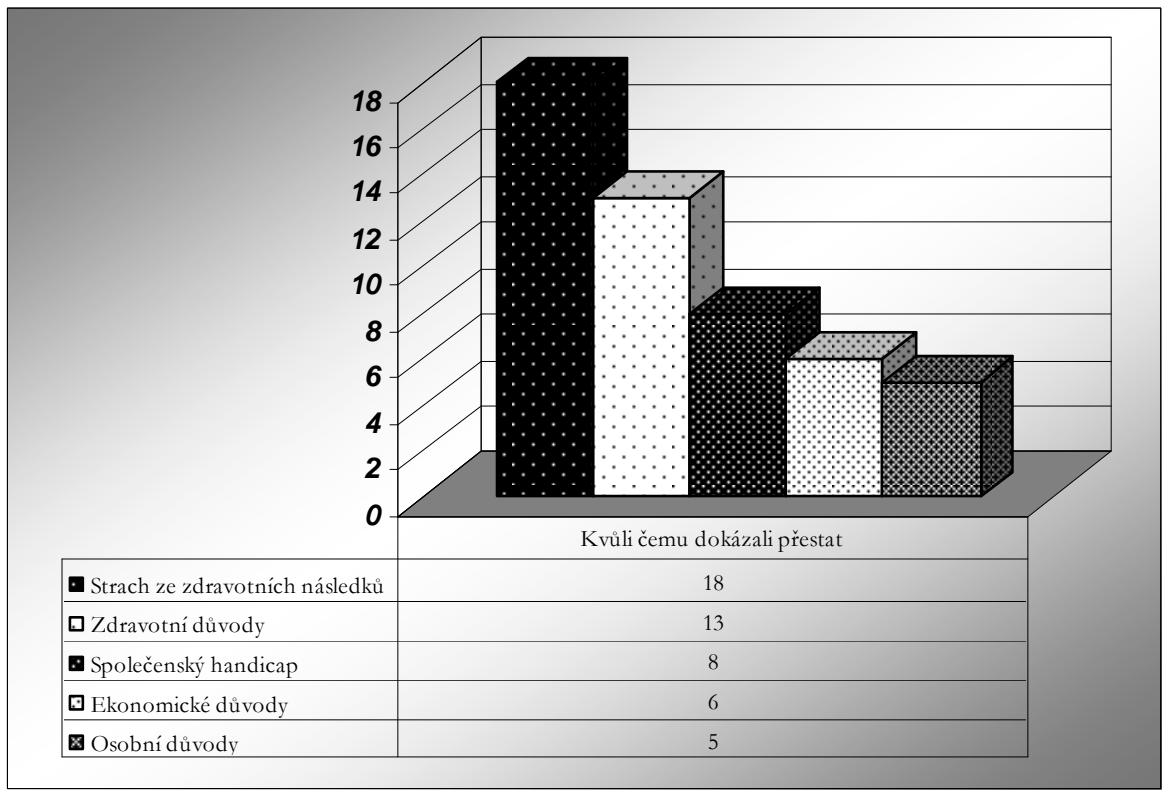

Za společenský handicap začalo postupně považovat kouření 8 čili $19 \%$ ze sledovaných kuřáků. Jako bezprostřední důvody nejčastěji uváděli nekuřácké okolí, to, že partner byl nekuřák nebo že jim začal vadit zápach z dýmu. Důvody ekonomické, tedy finanční náročnost a zbytečnost výdajů, uvedlo 6 respondentů (14 $\%), 5$ z nich (12\%) jako dominantní označilo důvody ryze osobní. Nejčastěji uváděli, že si chtěli vyzkoušet vlastní vůli, že partner měl zdravotní problémy a nechtěli mu prítěžovat nebo že nechtěli být omezováni nějakou závislostí.

\section{Prevence ani reklama nezabírají...?}

Z baterie otázek, věnovaných nekuřácké části sledované skupiny - celkem šlo o 54 osoby mimo jiné vyplynulo, že 23 z nich (43\%) neza- 
čaly kourrit, protože necítily žádnou potřebu, kouření jim spíše vadilo (graf č. 2). Třináct osob $(24 \%)$ uvedlo, že si vždy uvědomovaly škodlivost kouření, a proto s ním nikdy nezačaly. Deset respondentů vyrůstalo v kuřáckém prostředí a kouření rodiče nebo rodičů jim vadilo natolik, že nikdy nezačali. Šest osob (11\%) si uvědomovalo ekonomickou náročnost kouření, na pět (9\%) měli vpravdě výchovný vliv jejich rodiče, učitelé či další vychovatelé, dvě (4\%) aktivně sportovaly, a proto nikdy nekouřily.
Pro preventisty je jistě zajímavý údaj, že téměř dvě třetiny všech respondentů (62 osob, $64 \%$ ) uvedly, že na ně nikdy nepůsobila zdravotnická prevence o škodlivosti kouření. Na 35 respondentů (36 \%) prevence působila $\mathrm{z}$ forem nejčastěji uváděli články $\mathrm{v}$ tisku, publikace a přednášky odborníků. Ještě zajímavější je údaj o vlivu a účinnosti reklamy na tabákové výrobky. Její uvědomělý vliv potvrdili pouze tři dotázaní, tedy pouhá tři procenta všech respondentů, zatímco 94 respondenti (97\%) si její vliv nijak nepřipouští.

Graf č. 2 - Důvody proč nezačali kouřit

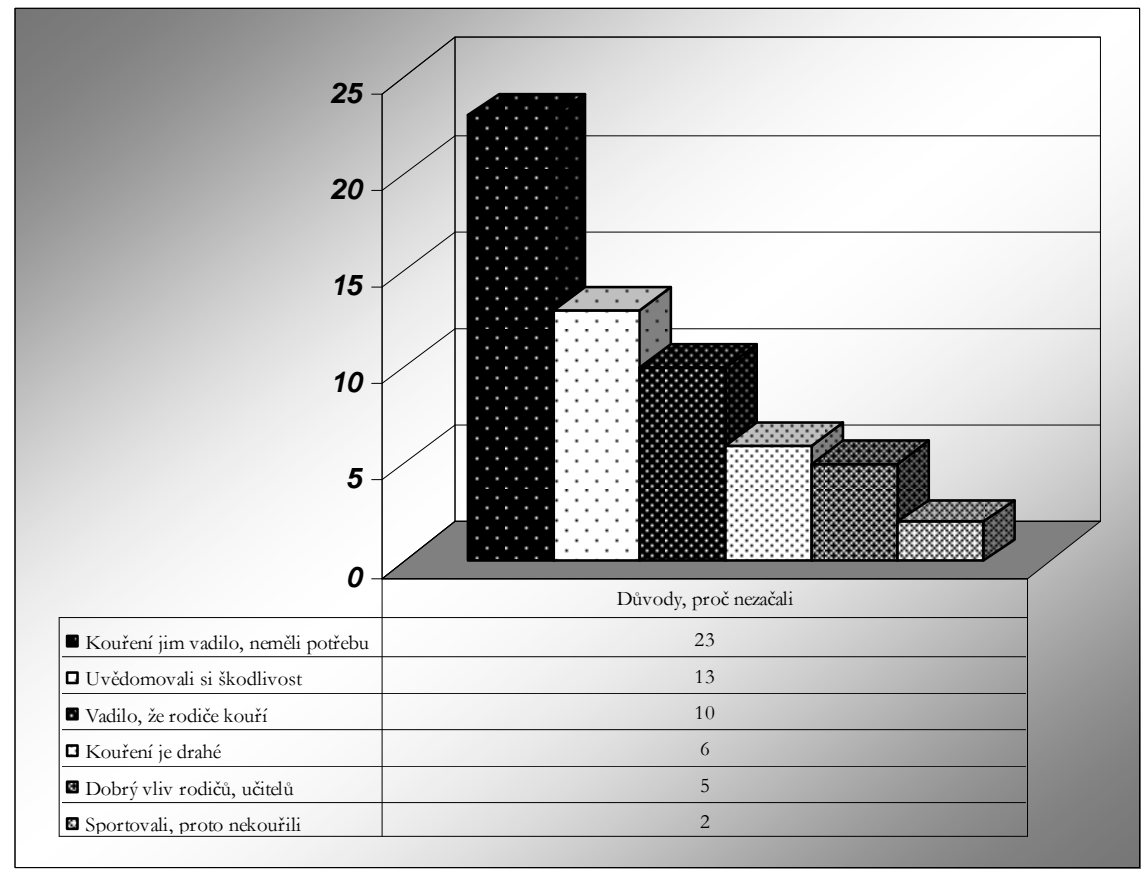

\section{Proč vůbec začínali?}

Téměř polovina respondentů - kuřáků (20 osob ze 43, $47 \%$ ) uvedla, že hlavním důvodem, proč začali kouřit, bylo potvrzení jejich statutu v neformální vrstevnické skupině - v partě, ve školním kolektivu, zkrátka mezi kamarády (graf č. 3). Přesný důvod nedokáže definovat pětina kouřících respondentů $(9,21 \%)$. Prvku módnosti podlehlo 5 kuřáků $(12 \%)$, zvědavost a pocit 
nedostatek pohybu (9 respondentů, $9 \%$ ), celkově špatný životní styl $(6,6 \%)$, obezitu (5,5\%), životní prostředí (4,4\%), alkohol (2,2\%), hluk
$(1,1 \%)$, a je vidět, že drogy $(1,1 \%)$ pro tuto generaci ještě žádnou roli nehrály a nehrají!

Graf č. 3 - Proč vlastně začínali

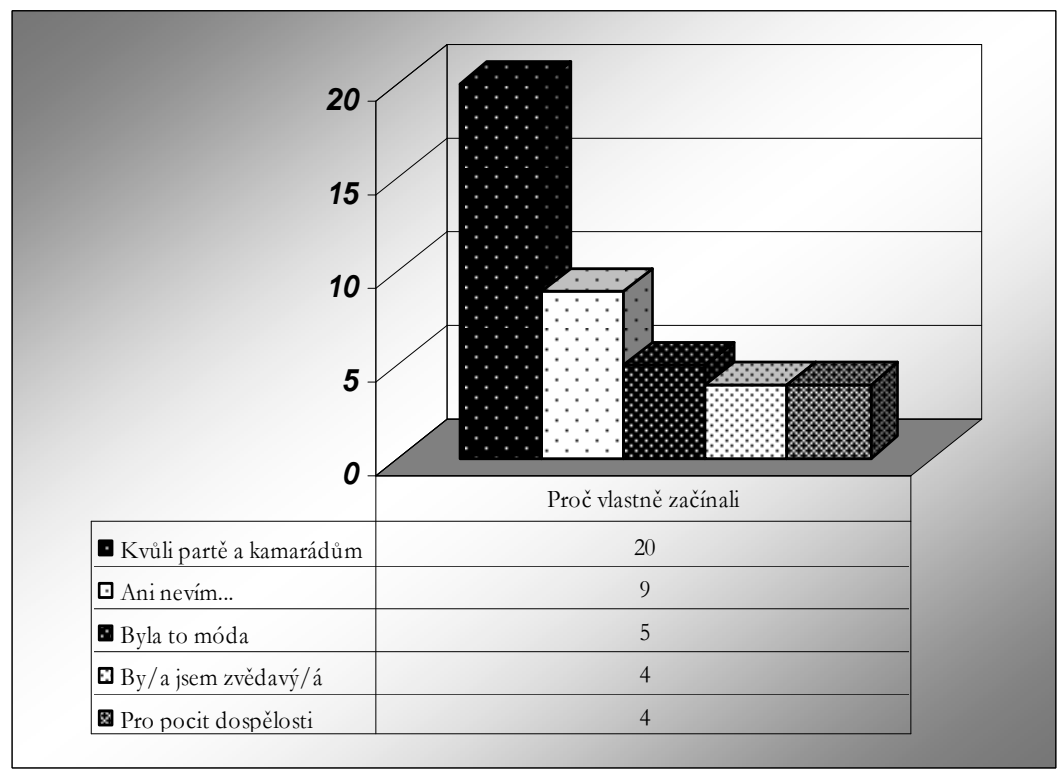

\section{ZÁVĚR}

Pracovali jsme se vzorkem 97 respondentů mezi padesáti až pětaosmdesáti roky věku, průměrný věk byl 64,5 roku. Čtyřicet čtyři procenta respondentů, celkem 43 osoby, uvedly, že někdy v minulosti kouřily, toto číslo je tedy ve srovnání s celkovým republikovým průměrem, kdy se uvádí kouření zhruba u $30 \%$ české populace, vyšší. Dnes kouří ze sledované skupiny kuřáků pouze 6 osob, kourít tedy dokázalo prestat, a to je jedno z nejdůležitějších zjištění studie, 37 ze 43 kuřáků, tedy plných $86 \%$ !

Druhým důležitým závěrem studie je potvrzení klesající hranice začátku pravidelného kouření. Průměrný věk první cigarety byl o sledovaného souboru 17,5 roku, začátek pravidelného kouření v průměru 20,4 roku. Tato věková hranice, $\mathrm{v}$ reálu spadající vzhledem $\mathrm{k}$ přihlédnutí $\mathrm{k}$ průměrnému věku respondentů zhruba do první poloviny šedesátých let minulého století, je o několik let vyšší, než naznačují současné studie, kdy již v kategorii mezi 15. až 18. rokem kouř́ $40-50 \%$ populace. Kuřáci ze sledovaného souboru kouřili v průměru 20,6 roku průměrně 12 cigaret denně. To představuje velmi přbližně asi 90000 vykouřených cigaret čili při dnešní ceně asi 3 koruny za kus zhruba 270.000, - korun. Hlavní prŕčcinou, proč začali kouřit, byl vliv kamarádů a party a vlastní pozice $\mathrm{v}$ ní, hlavní príćinou, proč skončili, byly obavy ze zdravotních následků nebo prímo zdravotní problémy kuřáků. Finanční náročnost kouření se projevila jako důvod pro ukončení u $14 \%$ sledovaných kuřáků. Kuřáci si př́liš nepřipouštěli pưsobení reklamy, vědomé ovlivnění reklamou připustili pouze 3 kourrící respondenti, na 62 respondentů ( $64 \%$ z celé skupiny) nijak nepůsobila zdravotnická prevence. 


\section{LITERATURA}

KALINA, K. et al.: Drogy a drogové závislosti 1. Praha: Úřad vlády České republiky, 2003. 319 s. ISBN 80-86734 $-05-6$.

KALINA, K. et al.: Drogy a drogové závislosti 2. Praha: Úřad vlády České republiky, 2003. 343 s. ISBN 80-86734 $-05-6$.

KEBZA, V.: Psychosociální determinanty zdraví. Praha: ACADEMIA, 2005. 263 s. ISBN 80-200-1304-5.
PRABHAT, J., CHALOUPKA, F. J.: Jak zvládnout kuřáckou epidemii. Praha: Státní zdravotní ústav, 2004. 111 s.

PROVAZNÍK, K. et al.: Manuál prevence v lékařské praxi. Souborné vydání, Praha: Univerzita Karlova - 3. lékařská fakulta, 2003, 2004. Nakladatelství Fortuna, 2003, 2004. 733 s.

SOVINOVÁ, H., CSÉMY, L.: Kouření cigaret a pití alkoholu v České republice. Praha: Státní zdravotní ústav, 2003. $92 \mathrm{~s}$. 